\title{
Phytoremediation of Lead-Contaminated Soil by Using Vetiver Grass (Vetiveria zizanioides L.)
}

\author{
Rawidh Said Abdallah ${ }^{1}$, Arief Rachmansyah ${ }^{2 *}$, Bagyo Yanuwiadi ${ }^{3}$ \\ ${ }^{1}$ Master Program of Environment Resources Management, Postgraduate School, University of Brawijaya, Malang, Indonesia \\ 2 Department of Civil Engineering, Faculty of Engineering, University of Brawijaya, Malang, Indonesia \\ ${ }^{3}$ Department of Biology, Faculty of Mathematics and Natural Sciences, University of Brawijaya, Malang, Indonesia
}

\begin{abstract}
Lead becomes a frequent problem in the environment, especially in the soil. However, there are plenty of plant species that can be used to overcome that problem. This study was aimed to analyze the effectiveness of Vetiver grass to reduce hyperaccumulate heavy metal such as lead $(\mathrm{Pb})$ in the soil. Moreover, this study focused on the determination of heavy metals in the soil before plantation and after plantation of Vetiver. The method used was by planting the Vetiver grass in soil that was already treated by lead nitrate, lead chloride, and lead sulfate. Samples were collected from these treated soil every two weeks and samples of the vetiver grass were taken after one week for ten weeks. The result shows that Vetiver grasses are able to remove hyper-accumulate lead from the treated soil.
\end{abstract}

Key words: Heavy metals, hyper accumulator, Vetiver grass.

\section{INTRODUCTION}

Environmental pollution is an issued topic since 50 years ago. Water and soil are already polluted in some places. It is getting polluted in several ways. There is urgency in controlling soil pollution to maintain soil fertility and increase productivity. Pollution can be defined as undesirable changes in physical, chemical and biological parameters of water, air and soil quality affecting human life, the life of plants and other useful living animals, industrial process, the living conditions, and cultural assets. Pollutants are something that interferes with the health, comfort, property or community environment. Generally, most pollutants are introduced in the environment by waste, accidental disposal or by-products or residues from the production of something useful. Some valuable natural resources such as air, water, and soil are increasingly polluted $[1,2]$.

Heavy metal pollution is now a main environmental concern because metal ions are not easily degraded in the environment due to their non-degradable properties. The tendency of heavy metal toxicity and bioaccumulation in the environment creates a chronic health problem of living organisms. Compared to organic contaminants,

\footnotetext{
* Correspondence Address:

Arief Rachmansyah

Email : ariefftub@yahoo.com

Address : Postgraduate School, University of Brawijaya, Mayjen Haryono No 169, Malang 65145.
}

heavy metals are not possible to be diminished by chemical or biological processes. Therefore, converting into less toxic species is the only possible solution [3]. At low concentration, most heavy metals are toxic and can infiltrate the food chain, thereby accumulate in and inflict in hazard to living species. Every metal has a potential to indicate harmful impacts at higher concentrations and the toxicity of each metal relies on the quantity exposed to the organism, the absorbed dose, the route and the duration of exposure [4].

Each heavy metal has a $5 \mathrm{~g} . \mathrm{cm}^{-3}$ molecular mass which is higher than average particle density of soil $\left(2.65 \mathrm{~g} \mathrm{~cm}^{-3}\right)$. Some heavy metals, for example, cobalt, iron, zinc, manganese, copper, or molybdenum are necessary for the organism growth. Meanwhile, other heavy metal s function in peroxidase and nitrogenation by vanadium $(\mathrm{V})$ or in hydrogenation by nickel (Ni). The rest of the heavy metals remain toxic to organisms including Lead, cadmium, Uranium, Chromium, Thallium, Mercury and Silver. Otherwise, Selenium (Se) and Arsenic (As) are not classified as heavy metals. However, since they partially possess toxicity characteristics similar to heavy metals, they are commonly called as metalloid in publications [5].

All soils contain heavy metals. No heavy metals, $\mathrm{Pb}, \mathrm{Zn}, \mathrm{Cu}, \mathrm{Ni}, \mathrm{Cd}$, and $\mathrm{Cr}$ concentrations are between 0.0001 and $0.065 \%$. Meanwhile, Manganese $(\mathrm{Mn})$ and Iron $(\mathrm{Fe})$ can range from $0.002 \%$ to $10.0 \%$, respectively. With the exception of iron, in the soil, all heavy metals with the 
concentration of more than $0.1 \%$ are toxic to vegetation thereby altering the structure of plant communities in contaminated habitats. Nonetheless, every plant organism has a certain threshold level for every heavy metal which causes toxicity. Specifically, plants that are able to adapt to living on heavy metal soil are known as metallophytes. The zinc-rich soil (0.1-10.0\% Zn) often contains high $\mathrm{Pb}$ content, but almost no $\mathrm{Cd}$, whereas the soil with a high concentration of copper (Cu) ranging from 0.1 to $3.2 \%$ has other heavy metals in higher concentrations such as $\mathrm{Pb}, \mathrm{Zn}, \mathrm{Ni}, \mathrm{Co}$, and $\mathrm{Cd}$ [5].

Mining gives negative impacts on the environment, causing ecosystem damage and changes, including loss of biodiversity and accumulation of environmental pollutants. Processing of ore is a major source of heavy metal pollution in the soil, and the restoration of the ecosystem from mining activities can take several decades. This activity creates a huge quantity of irons and dumps, which are often left neglected. Abandoned mines pollute water from the release of chemicals and particulates accumulated in water sources thus creating the need to treat contaminated heavy metal wastes, prior to discharge into the environment [6].

Other factors that affect the existence and levels of heavy metals in soils include the degree of complications with the ligand, density and type of charge in the soil colloids, and the relative surface area of the soil. The large interfaces and specific surface areas provided by the soil colloids help control heavy metal concentrations in natural soils. In addition, the soluble concentration of metals in contaminated soils can be reduced by soil particles with high specific surface area, although this may be metal specific. For example, McBride and Martinez reported that the addition of an amendment consisting of hydroxides with a highly reactive surface area reduces the solubility of $\mathrm{Cu}$, $\mathrm{Mo}, \mathrm{As}, \mathrm{Cd}$, and $\mathrm{Pb}$, meanwhile $\mathrm{Ni}$ and $\mathrm{Zn}$ remained insoluble. Soil aeration, microbial activity, and mineral composition have been reported to affect the level of heavy metals in the land [7].

The contamination of heavy metal in soil has become common throughout the world due to the increasing geological and anthropogenic activity. Plants growing on this soil show a decline in performance, growth, and harvest. Bioremediation becomes a suitable method to treat contaminated soils of heavy metals. This is a widely accepted method mostly done in situ. It is particularly suitable for the establishment/re-establishment of plants on the treated soil. Microorganisms and plants use different mechanisms for bioremediation of contaminated soil. Using plants for the treatment of contaminated soil is a more general approach in bioremediation of contaminated soils of heavy metals $[8,9]$.

Combining both microorganisms and crops is an approach to bioremediation that ensures more efficient cleaning of contaminated soils of heavy metals [10]. However, the success of this approach is highly dependent on the species of organisms involved in the process [7].

Phytoremediation is a technology that applies plants to clean pollutants in the environment. Benefits of phytoremediation include being an economical, energy-efficient and environmentallyfriendly method, having been able to be used in a large area, and being useful to resolve various contaminants (metals, organic substances or radionuclides) and the media of the planting activities such as mud, soil, water or sediment). Phytoremediation can be applied into many implementation methods which include phytoextraction, in which the soil is decontaminated by the plants to the air part through the process of heavy metal uptake and then the plants are harvested and dislocated from the site. Phytostabilization is a process of minimizing the mobility of heavy metals in contaminated soil by the plants. And Phytovolatilization, in which plants extract volatile metals from the soil and vaporize them from the leaves $[11,12]$.

A hyper accumulator means a plant that has the ability to grow on soil contaminated with heavy metals. Not only able to grow, the plant can also absorb heavy metals without occurring symptoms of phytotoxicity. The base type for the active hyper accumulator plant is in taking a substantial quantity of heavy metals from the soil. Moreover, heavy metals are translocated but are translocated to shoots and accumulated above the soil organ, especially the leaves without storing in the roots. Despite the different features, hyper accumulation also depends on hyper-tolerance which is an essential key property preventing heavy metal poisoning in plants. Around 450 species of 
angiosperm have been identified as far as heavy mortgage accumulators [13].

Vetiver comes from India and has been used traditionally since ancient times due to perfume obtained from roots. This planting effort of this plant species to rehabilitate the land using vetiver was started in 1956 by the National Botanical Garden, Lucknow (it is known as the National Botanical Research Institute) which shows that vetiver grass has an amazing ability. Those plant could help improving soil fertility and facilitate groundwater filling. Since then these have been made to implement vetiver plant in land reclamation and conservation by the support of state government in various parts of India. The World Bank also initiated several projects in India in the 1980s for the systematic development of Vetiver Grass Technology (VGT), now known as Vetiver System (VS) for watershed management, soil conservation and slope stabilization [14]. This research is aimed to analyze the effectiveness of Vetiver grass to reduce hyper-accumulate heavy metal such as lead (Pb) in the soil from Batu City.

\section{MATERIALS AND METHODS}

This research used a descriptive quantitative approach with experimental method since descriptive research relies on observation as a means of collecting data. It attempts to examine situations in order to establish what the norm is, i.e. what happen again under the same circumstances [15]. The descriptive research tries to systematically describe a problem, service, situation, phenomenon or program, or gives fix information or describes attitudes towards an issue. Based on Hyman [16], generally, in descriptive surveys, the aim is to study a large and heterogeneous population. Moreover, quantitative research is conducted according to the quantity or amount of measurement. It can be implemented to phenomena which are possible to be described in quantity [17].

\section{Materials}

The experiment was conducted from September to November 2017. The soil sample was taken from Batu City. The materials used in research were soil, vetiver grass, tap water, distilled water, and lead chloride. The types of equipment used in this study are Sieve, a standard flask with a capacity of $1000 \mathrm{~mL}$, sensitive balance, and nomination paper. Plastic bags were also used in the research.

\section{Research Procedure}

Three mol of lead chloride $(\mathrm{Pb} \mathrm{Cl})$ solution and six kilograms of soil were mixed and then were distributed into three plastic bags. The 45 gram of vetiver grass were planted in each plastic bag. Then about 45 grams vetiver grass planted per basin. The soil samples were taken and analyzed every two weeks. In the same time, samples of the vetiver grass were taken after a week, five weeks and ten weeks. The overall duration of this experiment was ten weeks.

The artificial treatment of heavy metals was prepared based on the range of heavy metal concentrations submitted by the Council of Canadian Ministry of the Environment [18] and the Department of Environment, Malaysia [19].

\section{RESULTS AND DISCUSSION Lead Compound in Soil}

Figure 1 shows that the difference in observation times influence or has different effects on the $\mathrm{Pb} \mathrm{Cl}$ contain in the Soil. The effect of vetiver grass is starting to shown at the observation times where the heavy metal-induced soil has decreased $\mathrm{Pb} \mathrm{Cl}$ after 2 weeks. However, at the last observation time (4 weeks) no further decreasing $\mathrm{Pb} \mathrm{Cl}$ in the Soil, compared to the 2 weeks observation. We assumed that it shows the ability of vetiver grass to reach its maximum level to remediate the heavy metal. This result was similar to the results of the previous study whereby the end of four days, most of the heavy metals had already been taken by plants [20].

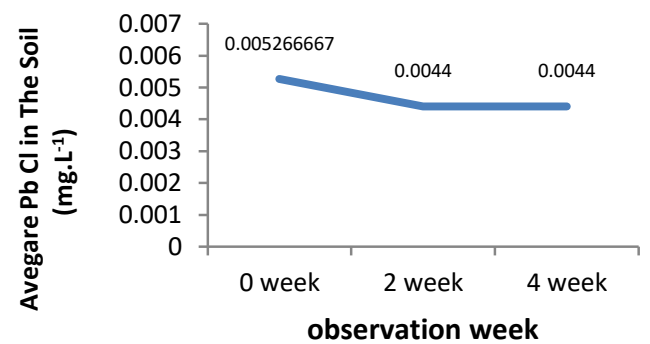

Figure 1. Concentration of Lead Compound in the Soil

Another research result showed heavy metals in soil, even at the level above critical value to plant growth, had no negative effect on vetiver growth $[21,22]$. Another study showed that some metals 
such as lead are largely immobile in soil and their extraction rate is by solubility and diffusion through the root surface [23].

\section{Lead Compound in Vetiver Grass}

Along observation times, different concentration of $\mathrm{Pb} \mathrm{Cl}$ in the Vetiver grass was measured. The changes in the $\mathrm{Pb} \mathrm{Cl}$ concentration started to appear after 5 weeks. After 1 week dap, the $\mathrm{Pb} \mathrm{Cl}$ in the vetiver increased, showing the absorption of $\mathrm{Pb} \mathrm{Cl}$ by the vetiver. Similar to the concentration of $\mathrm{Pb} \mathrm{Cl}$ in the soil, $\mathrm{Pb} \mathrm{Cl}$ in the vetiver grass for the observation in $10^{\text {th }}$ week is at the same concentration, i.e. $0.0044 \mathrm{mg} . \mathrm{L}^{-1}$, which means no more decreasing of $\mathrm{Pb} \mathrm{Cl}$ concentration.

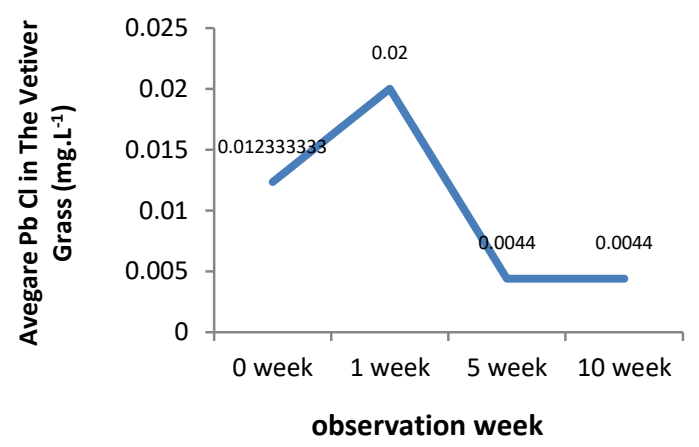

Figure 2. Concentration of Lead Compound in the Vetiver Grass

Truong [24] presented a similar result on his research that the vetiver grass will take $\mathrm{Pb}$ slowly and continuously for long periods. Similar findings were also observed previously [25], which reported that vetiver grass showed high tolerance to a very adverse condition, thereby making it possible to be employed for mine rehabilitation, tailings industrial waste dumps and garbage landfills that usually contain high acid or alkaline levels and possess high degree of heavy metals, while having low plant nutrients. Another study explained the most conspicuous characters of vetiver grass includes its fast growth, large biomass, strong root system, and high level of metal tolerance [26]. Therefore, vetiver grass is an important candidate for stabilization of metal-contaminated soils. Truong [21] also demonstrated that vetiver is highly tolerant to many heavy metals.

\section{Limitation and Recommendation}

This research was expected to give some parts of recommendation for phytoremediation study in the future, which meant to focus more on analyzing the effects of heavy metals on human health and the use of plants for the treatment of these biomaterials. The government is expected to take steps to reduce soil and environmental pollution from harmful contaminants such as nondumping plant remnants to the ground.

The complexity of factors that control the efficiency of these techniques, such as soil properties, plant species and climatic conditions, courage the fact that more research needs to be done. More species that have remediation capabilities need to be identified, especially crops that can contribute to the social and economic development of local people, such as industrial species. Also, in the future, research should focus on developing agricultural techniques to improve phytoremediation efficiency and reduce the time and cost of heavy metal removal from the soil. The success of some industrial residues to increase heavy metal phytoavailability can be investigated. An important advantage of fragrant roots (such as in the vetiver grass) is that it is not considered to be a hazardous waste that can be safely used for bioenergy production, compost or even as a craft material.

\section{CONCLUSION}

Phytoremediation is a promising green technology that can be used to remediate heavy metal-contaminated soil. In developing countries, this technology can provide low-cost solutions to recover contaminated areas, especially abandoned industrial sites (mines and garbage dumps). The results of experiments show that the vetiver of the ecotype has a high potential for absorbing heavy metals contaminated in the soil. Although vetiver is not an accumulator, it has proven to be extremely tolerant of very adverse land conditions. Therefore, vetiver is possible to be applied for mine rehabilitation, tailings mining and industrial waste that is often very acidic or alkaline in heavy and low metals in plant nutrients. According to these experimental results, the lead $(\mathrm{Pb} \mathrm{Cl})$ remaining on the soil gradually begins to decrease as the increased contact time of the experiments proves the efficiency of the plant in phytoremediation even in high concentrations of heavy metals. 


\section{REFERENCES}

[1] Ashraf, M.A., M.J. Maah, I. Yusoff. 2014. Soil contamination, risk assessment and remediation. In: Soriano, M.C.H. (Ed). Environmental Risk Assessment of Soil Contamination. 3-56. DOI: 10.5772/57287.

[2] Leksono, A.S., B. Yanuwiadi. 2014. The Effect of bio and liquid organic fertilizer on weight and quality of apple. Int. J. Agron. Agr. Res. 5(5). 53-58.

[3] Ayangbenro, A.S., O.O. Babalola. 2017. A new strategy for heavy metal polluted environments: a review of microbial biosorbents. Environ. Res. Public. Health. 14(1). E94.

[4] Mani, D., C. Kumar. 2014. Biotechnological advances in bioremediation of heavy metals contaminated Ecosystems: An overview with special reference to phytoremediation. Int. J. Environ. Sci. Technol. 11. 843-872.

[5] Bothe, H. 2011. Plants in heavy metal soils. In: Detoxification of heavy metals Springer Berlin Heidelberg. 35-57.

[6] Adler, R.A., M. Claassen, L. Godfrey, A.R. Turton. 200. Water, mining and waste: An historical and Economic perspective on conflict management in South Africa. Econom. Peace Secur. J. 2. 32-41.

[7] Chibuike, G.U., S.C. Obiora. 2014. Heavy metal polluted soils: effect on plants and bioremediation methods. Appl. Environ. Soil Sci. 1-12.

[8] Oktaviani, R., B. Yanuwiadi. 2016. Analisis vegetasi riparian di tepi Sungai Porong, Kabupaten Sidoarjo. Jurnal Biotropika. 4(1). 25-31.

[9] Kurniawan, H., B. Yanuwiadi, S. Soemarno. 2016. Persepsi masyarakat malam (studi kasus di Dusun Rembang II Desa Rembang Kec. Rembang Kab. Pasuruan). Jurnal Pembangunan dan Alam Lestari. 7(1). 76-85.

[10] Oktaviani, R., B. Yanuwiadi. 2016. Persepsi Masyarakat Terhadap Konservasi Spesies Riparian di Tepi Sungai Porong, Kabupaten Sidoarjo. Jurnal Biotropika. 4 (3): 81-87.

[11] Cunningham, S.D., W.R. Berti, J.W.W. Huang. 1995. Phytoremediation of contaminated soils. Trends Biotechnol. 13. 393-397.

[12] Wantouw, S., Antariksa, B. Yanuwiadi, Z. Tamod. 2014. Perception and participation on co-management of green open space in coastal reclamation area Manado. Int. J. Appl. Sociol. 4(4). 108-113.

[13] Rascio, N., F.N. Izzo. 2011. Heavy metal hyperaccumulating plants: how and why do they do it? And what makes them so interesting? Plant Sci. 169-181.

[14] Lavania, U.C. 2008. Vetiver in India: historical perspective and prospective for development of specific genotypes for environmental or industrial application. In: Truong, P. (Ed). Proceeding of $1^{\text {st }}$ Indian Vetiver Workshop Vetiver System for Environment Protection and National Disaster Management, Cochin, India. 40-47.

[15] Walliman, N.S.R. 2001. Your research project: a step-by-step guide for the first-time researcher. Sage Publications, Ltd. London.

[16] Hyman, H.H. 1955. Survey design and analysis: principles, cases, and procedures. Free press.

[17] Kothari, C.R. 2004. Research methodology: methods and techniques, $2^{\text {nd }}$ Ed. New Age International Publishers.

[18] CCME. 1999. Canadian environmental quality guidelines. Canadian Ministry of the Environment. Canada.

[19] DOE. 2009. Guidance document on Health Impact Assessment (HIA) in Environmental Impact Assessment (EIA). Department of Environment, Malaysia.

[20] Lim-Suelee, A., S.N.M. Syed-Hasan, F. MohdKusin, F. Mohamat-Yusuff, Z. Zaiton-Ibrahim. 2017. Phytoremediation potential of vetiver grass (Vetiveria zizanioides) for treatment of metal-contaminated water. Water Air Soil Pollut. 228(4). 158.

[21] Truong, P.N.V. 1999. Vetiver grass technology for mine rehabilitation. PRVN Technical Bulletin No. 1999/2. Office of the Royal Development Projects Board, Bangkok, Thailand.

[22] Roongtanakiat, N., P. Chairoj. 2001. Uptake potential of some heavy metals by vetiver grass. Kasetsart. J. Nat.Sci. 35.46-50.

[23] Lombi, E., F.J. Zhao, S.J. Dunham, S.P. McGrath. 2001. Phytoremediation of heavy metal-contaminated soils: natural hyperaccumulation versus chemically enhanced 
phytoextraction. J. Environ. Qual. 30. 19191926.

[24] Truong, P.N.V. 2000. The global impact of vetiver grass technology on the environment. In: Proceedings of $2^{\text {nd }}$ international Vetiver Conference, Thailand. 46-57.

[25] Roongtanakiat, N., P. Chairoj. 2001. Vetiver grass for the remediation of soil contaminated with heavy metals. Kasetsart J. Nat. Sci. 35. 433-440.

[26] Raskin, I., B.D. Ensley. 2000. Phytoremediation of toxic metals. John Wiley and Sons, Inc. New York. 